\title{
Sor J uana Inés de la Cruz, Primero sueño y otros escritos. Prólogo de Elena del Río. México, FCE, 2006. (Colec. Aula Atlántica)
}

Esta nueva antología que presentó el Fondo de Cultura Económica sobre la obra de sor J uana I nés de la Cruz, aún cuando incompleta en mi opinión, es acertada en la selección de textos. Sigue la división establecida por don Alfonso Méndez Plancarte en la primera investigación crítica sobre Sor J uana editada en cuatro volúmenes en 1995 por el propio.

Es muy aplaudible el hecho de que incorpore entre sus textos, Ia Ilamada "Carta de Monterrey"-Autodefensa personal, en la antología- ya que es poco conocida por el público no especialista interesado en la obra de Sor J uana y representa un texto fundamental en el revisionismo histórico del siglo XX sobre la vida y obra de la jerónima, sobre todo desde la aparición de las reflexiones de don Antonio Alatorre en 1980, "Para leer la Fama y obras póstumas de Sor J uana I nés de la Cruz" aparecida en el número 29 de la Nueva Revista de Filología Hispánica.

Sin embargo, hay dos omisiones importantes; por una parte, no hay la menor referencia a "El enigma de Serafina de Cristo", datada el 1 de febrero de 1691 (posterior a la "Respuesta a sor Filotea de la Cruz") manuscrito polémico que don Elías Trabulse atribuye a Sor J uana y que merece la pena su difusión; por otra parte, se echa de menos, en falta también alguna muestra de Los enig- mas ofrecidos a la casa del placer publicados en Lisboa en el año de 1695, muy poco tiempo antes de la muerte de la jerónima y quetiran por tierra parte dela interpretación sobre la "renuncia final del mundo", en susúltimosaños de vida.

Es también interesante destacar que la antología ofrece diez temas de investigación y una bibliografía básica que contiene al gunas obras indispensables paraintroducirse o profundizar en ciertos aspectos delaviday obrade Sor J uana. Además, proporciona los títul os de al gunos textos literarios inspirados en su vida y obra, así como la filmografía que se ha hecho sobre ella.

El prólogo, sin embargo, deja mucho que desear tanto en su forma, como en su contenido. Por una parte, Ia redacción es deficiente, tanto en su coherencia, como en su cohesión; baste como ejemplos apuntar los abusos de gerundios (muchas veces como cal cos del inglés), reiteración de leísmos, ideas desarroIladas a medias, sal to de una idea a otra sin relación ninguna, por citar los más evidentes. Por otra parte, la prol oguista presenta a una Sor J uana vetusta, superficial y mojigata, visión que desvirtúa y minimiza la figura histórica de la jerónima y, además, malinterpreta datos y desconoce lecturas que hoy son ya del dominio de los especial istas en el tema.

Como ejemplo, baste señalar que la 
prologuista asegura que Nuñez de Miranda expulsa de su tutela espiritual a Sor J uana durante dos años, aún cuando ella misma reseña la Carta de Monterrey enviada en 1680 y que aparece en esta antología; en ésta es clarísimo que es la jerónima quien rechaza como confesor al jesuita, revelación que echó por tierra la interpretación clásica-debida al padre Oviedo, hagiógrafo de Nuñez de Miranda- que aseguraba que era él quien la había abandonado. Sor J uana, para finalizar la carta, y tras ciertas ironías, más o menos veladas, contra el jesuita, le sugiere que la deje en paz _ ‘ $Y$ assí le suplico a V.R. que si no gusta ni es ya servido de favorecerme (que esso es vol untario) no se acuerde de mi...", pues si el problema era algo tan nimio para ella como el estudiar privadamente y el hacer versos, no había solución para el mismo. Sarcásticamente ella lo despide, diciéndole:

que aunque sentiré tanta pérdida mucho,

nunca podréquejarme, queDiosme crióy

redimió y que usa conmigo tantas misericordias,

proveherá con remedio para mi alma, que espero

en su vondad no se perderá, aunque le falte la

dirección de V.R.

[Carta]

Para insistir líneas más abajo:

“...aunque me falte la dirección de V.R., que el cielo hacen muchas Ilaves, y no se estrechó a un solo dictamen, sino que hay infinidad de manciones para diversos genios.... ¿Qué precisión ay en que esta salvación mía sea por medio deV.R.?..."

Con estas evidencias, se puede concluir que sor J uana demuestra a Nuñez la carencia de argumentos racionales para obligarla a cambiar la dirección de su "natural tendencia", por lo que su propio enojo contra ella carece de sustentación real y es, en últimainstancia, una terquedad de Nuñez por lo que ella podrá:

Elexir libremente padre espiritual el que yo quisiere, que si como Nuestro Señor inclinó a V.R. con tanto amor y fuerza, mi voluntad conformará también mi dictamen, no fuera otro que V.R.

[Carta]

Finalmente, se despide de él, insistiendo en que "si no gusta favorecerme no se acuerde de mí si no fuere para encomendarme al Señor".

Es cierto, como sabemos, que Sor J uana no podía imaginarse cuando esto escribía que sería ella misma, unos doce años después quien, por algún motivo que todavía no cabal mente explicado, acudiría — humillada y sumisaen su búsqueda.

Así, para concluir, me parece un tanto desacertado seguir insistiendo en publicar este tipo de apreciaciones máxime cuando, si el lector comienza a percatarse de los errores, abandona enseguida la lectura de la obra.

LAUS DEO

Cristina Simón CEPE-UNAM 